\title{
Optimalisasi Teknologi Fotobioreaktor Mikroalga sebagai Dasar Perencanaan Strategi Mitigasi $\mathrm{Gas}_{\mathrm{CO}}$
}

\author{
Ratna R. Rusdiani ${ }^{1}$, Rachmat Boedisantoso ${ }^{1}$, dan Muhammad Hanif ${ }^{2}$. \\ ${ }^{1}$ Jurusan Teknik Lingkungan, Fakultas Teknik Sipil dan Perencanaan, \\ Institut Teknologi Sepuluh Nopember (ITS) \\ Jl. Arief Rahman Hakim, Surabaya 60111 Indonesia \\ ${ }^{2}$ Pusat Teknologi Lingkungan, Badan Pengkajian dan Penerapan Teknologi \\ Kawasan Puspiptek, Gedung Geostech 820, Tangerang Selatan 15314 Indonesia \\ e-mail: ratnarzky@gmail.com, boedisantoso@its.ac.id, muhammad.hanif@bppt.go.id
}

\begin{abstract}
Abstrak-Pengendalian emisi gas $\mathrm{CO}_{2}$ sangat dibutuhkan untuk mengurangi efek Gas Rumah Kaca (GRK). Penerapan Carbon Capture Storage (CCS) dapat menjaga stabilitas $\mathrm{CO}_{2}$ dan mencegah pelepasan $\mathrm{CO}_{2}$ ke atmosfer dalam upaya mitigasi global. Salah satu bentuk teknologi CCS yaitu menggunakan kultur mikroalga dalam fotobioreaktor. Optimalisasi fotobioreaktor dengan menggunakan mikroalga air laut jenis Chlorella sp. Pengoperasian alat dilakukan secara step running dengan variasi acak sesuai matriks Design-Expert. Performa terbaik fotobioreaktor dilihat berdasarkan tingkat penyerapan gas $\mathrm{CO}_{2}$ dan produktivitas mikroalga tertinggi. Kondisi optimum hasil percobaan didapatkan dengan variasi kecepatan aliran fluida $23 \mathrm{~cm} /$ detik dan laju alir injeksi gas $\mathrm{CO}_{2} 0,61 \mathrm{ml} /$ detik. Produktivitas mikroalga yang didapatkan sebesar 0,405 gram/liter. Sedangkan kondisi optimum berdasarkan DesignExpert didapatkan dengan variasi kecepatan aliran fluida 25,82 cm/detik dan laju alir injeksi $\mathrm{CO}_{2} 0,61 \mathrm{ml} /$ detik. Produktivitas mikroalga yang didapatkan sebesar 0,427 gram/liter. Gas $\mathrm{CO}_{2}$ yang terserap tiap gram mikroalga sebesar 0,638 gram.
\end{abstract}

Kata Kunci-CCS, Chlorella sp., $\mathrm{CO}_{2}$, Fotobioreaktor, GRK

\section{PENDAHULUAN}

$\mathrm{G}$ AS $\mathrm{CO}_{2}$ merupakan komponen utama gas rumah kaca yang menyebabkan pemanasan global dan perubahan iklim (UNFCCC, 2008). Pada saat ini, konsentrasi $\mathrm{CO}_{2}$ di atmosfer sekitar $383 \mathrm{ppm}$ atau $0,0383 \%$ volume atmosfer (KEMENLH, 2012). Emisi $\mathrm{CO}_{2}$ dalam konsentrasi yang tinggi $(10 \%-12 \%)$ dihasilkan oleh aktivitas pembakaran bahan bakar fosil khususnya dari kegiatan industri. Oleh karena itu, dibutuhkan solusi teknologi untuk mengurangi tingginya emisi $\mathrm{CO}_{2}$ di atmosfer (Santoso dkk., 2012). Upaya yang tengah menjadi perhatian adalah pemanfaatan teknologi penambatan dan penyimpanan karbon atau Carbon Captue and Storage (CCS) (Sopiah dkk., 2012).

CCS merupakan teknologi untuk menangkap emisi $\mathrm{CO}_{2}$ untuk mencegah pelepasan $\mathrm{CO}_{2}$ ke atmosfer (Franca dan Adisa, 2015). CCS direkomendasikan oleh UNFCCC sebagai salah satu opsi utama teknologi mitigasi $\mathrm{CO}_{2}$ sejak 2006. Teknologi CCS dapat menangkap hingga $90 \%$ emisi $\mathrm{CO}_{2}$ dari pembangkit listrik atau fasilitas industri (C2ES, 2012). Teknologi penyerapan karbon yang menjanjikan adalah teknologi biologis menggunakan kultur mikroalga. Penerapan teknologi ini membutuhkan integrasi dengan teknologi pemanfaatan mikroalga sehingga tercipta sistem yang berkelanjutan dan ramah lingkungan (Hanif dan Dian, 2015).

Mikroalga merupakan tumbuhan mikroskopis bersel tunggal yang dapat menyerap $\mathrm{CO}_{2}$ dalam upaya menurunkan kadar $\mathrm{CO}_{2}$ di udara (Mulyanto, 2010). Mikroalga dapat memfiksasi $\mathrm{CO}_{2}$ (10 - 50) kali lebih efisien dibandingkan dengan tumbuhan (Wang dkk., 2008). Pengembangbiakan mikroalga untuk mendapatkan kepadatan sel yang tinggi dilakukan dalam bioteknologi mikroalga dengan desain reaktor dan proses yang optimal (Barbosa, 2003).

Chlorella sp. termasuk dalam kelompok organisme protista autotrof yang mampu membuat makanannya sendiri. Organisme ini memiliki pigmen klorofil, sehingga dapat melakukan proses fotosintesis. Chlorella $s p$. termasuk salah satu kelompok alga hijau yang paling banyak jumlahnya diantara alga hijau lainnya. Chlorella $s p$. melimpah di perairan tawar dan air laut (Pitriana dan Rahmatia, 2008). Pada penelitian ini, Chlorella sp. digunakan karena mampu memfiksasi $\mathrm{CO}_{2}$, kecepatan tumbuhnya yang cepat juga produksi biomassa yang dihasilkan sangat bermanfaat bagi kehidupan (Sopiah dkk., 2012).

Fotobioreaktor merupakan reaktor tembus pandang yang dilengkapi dengan instalasi suplai media dan emisi gas untuk mengkultur mikroalga dan menyerap $\mathrm{CO}_{2}$ (Widyaningrum dkk., 2013). Teknologi fotobioreaktor diketahui mampu meningkatkan produktivitas mikroalga sebesar dua hingga lima kali lebih tinggi dari kondisi normalnya (Setiawan dkk., 2009). Kecepatan pertumbuhan mikroalga dipengaruhi kecepatan aliran fluidanya (Hadiyanto dkk., 2010). Laju alir injeksi gas $\mathrm{CO}_{2}$ bertujuan untuk melihat kapasitas penyerapan $\mathrm{CO}_{2}$ oleh mikroalga (Santoso dkk., 2012).

Penelitian ini dilakukan untuk mendapatkan performa terbaik fotobioreaktor mikroalga dengan memvariasikan kecepatan aliran fluida dan laju alir injeksi gas $\mathrm{CO}_{2}$. Optimalisasi teknologi fotobioreaktor ini diharapkan dapat digunakan sebagai dasar perencanaan strategi mitigasi gas $\mathrm{CO}_{2}$ dengan alternatif teknologi yang ramah lingkungan. 


\section{METODE PENELITIAN}

\section{A. Persiapan Penelitian}

Persiapan penelitian yang dilakukan terdiri dari perijinan, persiapan bahan, dan persiapan alat yang digunakan. Bahan yang digunakan meliputi: gas $\mathrm{CO}_{2}$ murni (injeksi), kultur Chlorella sp., media (air laut), nutrien Agriculture-grade NPK, dan aquades. Alat yang digunakan meliputi: rangkaian sistem airlift fotobioreaktor 100 liter, $\mathrm{pH}$ meter, lux meter, thermometer, kertas saring, vaccum filter, oven, timbangan analitik, penjepit, alumunium foil, botol sampel, dan glassware, serta perangkat lunak Design-Expert.

Tabel 1.



Gambar 1. Rangkaian Sistem Airlift Fotobioreaktor 100 liter

\section{B. Pelaksanaan Penelitian}

Variasi yang digunakan yakni kecepatan aliran fluida (17 $\mathrm{cm} /$ detik $-30 \mathrm{~cm} /$ detik) dan laju alir injeksi gas $\mathrm{CO}_{2}(0,18$ $\mathrm{ml} /$ detik $-0,54 \mathrm{ml} /$ detik).

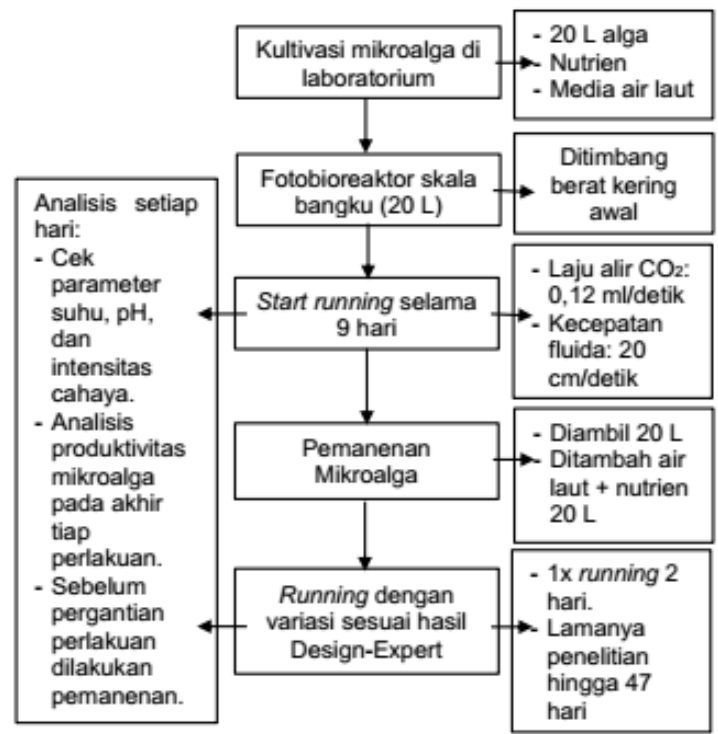

Gambar 2. Skenario Pelaksanaan Penelitian

Pengambilan sampel dalam fotobioreaktor sebanyak dua kali setiap hari pukul 10.00 dan 15.00. Pengukuran parameter suhu, $\mathrm{pH}$, dan intensitas cahaya dilakukan saat pengambilan sampel. Penelitian dilakukan di luar ruangan, sehingga semua parameter berjalan sesuai kondisi alam.

\section{Analisis Data dan Pembahasan}

Analisis data dan pembahasan dilakukan terhadap sampel Chlorella sp. Produktivitas mikroalga didapatkan dengan metode analisis berat kering. Data produktivitas mikroalga berdasarkan hasil penelitian kemudian diolah menggunakan Analysis of Variance (ANOVA) dengan perangkat lunak Design-Expert. Analisis dilakukan untuk mendapatkan kondisi optimal kinerja fotobioreaktor. Data hasil penelitian akan menghasilkan persamaan polynomial yang digunakan sebagai respon prediksi untuk variabel yang tidak diuji pada penelitian. Kondisi optimal berdasarkan hasil penelitian kemudian diolah menggunakan persamaan gas ideal untuk mengetahui $\mathrm{CO}_{2}$ yang terserap tiap gram mikroalga.

\section{HASIL DAN PEMBAHASAN}

\section{A. Kultur Chlorella sp.}

Kultur Chlorella sp. didapatkan dari Laboratorium PTLBPPT Serpong. Chlorella sp. berwarna hijau, bersifat planktonis yang melayang di perairan, dan relatif mudah dikultur dalam waktu yang singkat karena kemampuannya beradaptasi dengan kondisi lingkungan baru.

Kultur Chlorella sp. awal disiapkan $20 \%$ v/v reaktor atau sebanyak 20 liter dengan produktivitas mikroalga awal mencapai 0,100 gram/liter dengan kepadatan sel 1,4×105 $\mathrm{sel} / \mathrm{ml}$. Kultur Chlorella sp. kemudian dimasukkan ke dalam fotobioreaktor (banch scale unit) dan ditambah 80 liter media air laut dan nutrien. Setiap akan melakukan perubahan perlakuan, dilakukan pemanenan mikroalga untuk me-refresh atau mengembalikan sel-sel yang sudah tua atau mati.

\section{B. Pengoperasian Fotobioreaktor}

Fotobioreaktor dioperasikan secara step running dengan perubahan perlakuan sesuai variasi perangkat lunak DesignExpert. Penelitian dilakukan menggunakan metode respon permukaan Design-Expert dengan 8 nilai faktorial dan 5 nilai tengah yang disesuaikan dengan model kuadrat penuh. Kombinasi dengan nilai-nilai tersebut disebut dengan matriks eksperimen. Lima pengulangan nilai tengah berfungsi untuk memperkirakan kesalahan murni. Percobaan yang dirancang dalam matriks percobaan tersebut dilakukan dalam urutan acak yang berfungsi untuk memaksimalkan efek variabilitas dari respon yang diamati (Hanif dkk., 2012).

Variasi yang digunakan dikonversi untuk memudahkan pengoperasian alat, dimana:

1. Kecepatan aliran fluida

$$
\begin{array}{lcc}
\text { Minimum } & : 17 \mathrm{~cm} / \text { detik } & \approx 25 \mathrm{~Hz} \\
\text { Maksimum } & : 30 \mathrm{~cm} / \text { detik } & \approx 45 \mathrm{~Hz}
\end{array}
$$

2. Laju alir injeksi $\mathrm{CO}_{2}$

$$
\text { Minimum : } 0,18 \mathrm{ml} / \text { detik } \approx 3 \mathrm{bps}
$$$$
\text { Maksimum : 0,54 ml/detik } \approx 9 \text { bps }
$$

Gambar 3. menunjukkan grafik rekaman pengoperasian fotobioreaktor mikroalga selama 47 hari. Hari ke-0 hingga hari 


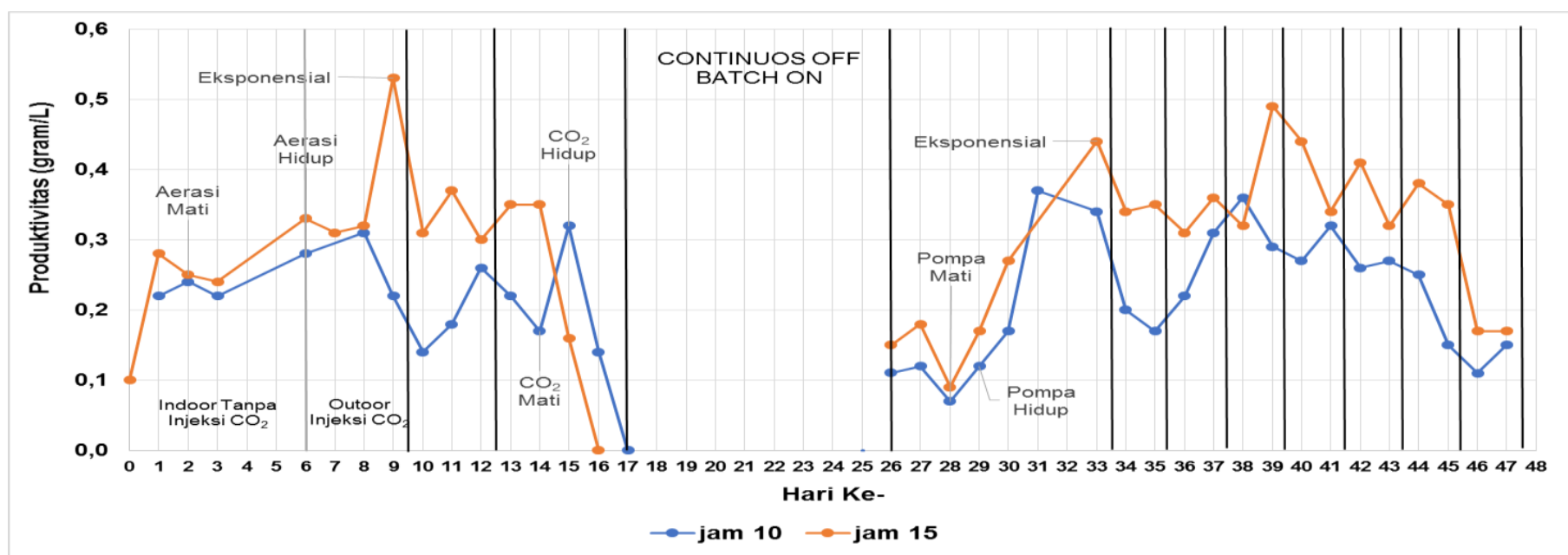

Gambar 3. Grafik Hasil Produktivitas Chlorella $s p$

ke-9 merupakan data produktivitas mikroalga sebelum diberikan variasi berdasarkan Design-Expert sebagai tahap adaptasi mikroalga hingga didapatkan grafik rata-rata pertumbuhan yang cenderung meningkat. Namun, terjadi penurunan pada hari kedua ketika aerasi dimatikan. Aerasi diberikan menggunakan aerator yang akan menghasilkan gelembung (bubbles) pada dasar reaktor. Aerasi berfungsi sebagai pengaduk (sirkulasi) media dan mikroalga dalam fotobioreaktor. Pengadukan dapat mencegah terjadinya pengendapan sel dan meningkatkan pertukaran gas ke media.

Variasi berdasarkan matriks Design-Expert dimulai pada hari 10 setelah dilakukan pemanenan pada hari 9. Rata-rata produktivitas mikroalga pada hari 9 sebelum pemanenan adalah 0,375 $\pm 0,1969$ gram/liter. Hari 10 didapatkan rata-rata produktivitas mikroalga turun menjadi 0,225 $\pm 0,0985$ gram/liter dan meningkat pada hari 11 dan 12 .

Variasi kedua dimulai pada hari 13 setelah dilakukan pemanenan pada hari 13 pukul 08.00 dan variasi dimulai pukul 09.00. Rata-rata produktivitas mikroalga setelah pemanenan adalah 0,260 $\pm 0,056$ gram/liter dan meningkat hingga $0,285 \pm 0,0755$ gram/liter pada hari yang sama dalam analisis pukul 10.00. Hasil ini menunjukkan bahwa Chlorella sp. beradaptasi cukup baik dengan perubahan perlakuan yang cukup ekstrim. Hari 14 rata-rata produktivitas mikroalga mengalami penurunan dan mati pada hari 16 pukul 15.00 .

Sebelum dilakukan kultur mikroalga baru, dilakukan pengurasan reaktor. Pengurasan reaktor ini menggunakan air dan ditambah dengan Hidrogen peroksida $\left(\mathrm{H}_{2} \mathrm{O}_{2}\right) . \quad \mathrm{H}_{2} \mathrm{O}_{2}$ digunakan sebagai desinfektan sehingga mikroalga yang masih menempel pada dinding reaktor benar-benar mati dan tidak menjadi racun bagi pertumbuhan sel mikroalga baru.

Kultur baru dalam fotobioreaktor dimulai pada hari 26. Hari 26 hingga hari 33 merupakan data rata-rata produktivitas mikroalga sebelum dimulai variasi berdasarkan Design-Expert. Produktivitas mikroalga awal mencapai 0,130 gram/liter dengan kepadatan sel $3,1 \times 10^{5} \mathrm{sel} / \mathrm{ml}$. Terjadi penurunan yang sangat drastis pada hari 28 ketika pompa dimatikan. Pompa berperan dalam mengatur keceptan aliran fluida dalam reaktor. Kecepatan aliran fluida berperan dalam pengadukan dan sirkulasi sel untuk mencegah pengendapan serta pendistribusian nutrien dan cahaya secara merata.

Variasi 3 sampai 9 berdasarkan matriks Design-Expert kembali berjalan pada hari 34 sampai hari 47. Hasil analisis menunjukkan peningkatan rata-rata produktivitas mikroalga terjadi pada variasi 4 dan 9 . Rata-rata produktivitas mikroalga pada variasi $3,5,6,7$, dan 8 mengalami penurunan. Hal ini dapat disebabkan karena ketidakcocokan pengaturan pada salah satu variabel. Injeksi $\mathrm{CO}_{2}$ yang terlalu sedikit dan kecepatan aliran fluida yang terlalu tinggi dapat menyebabkan penurunan produktivitas mikroalga.

Hasil produktivitas mikroalga rata-rata Chlorella sp. tiap perlakuan disajikan pada Tabel 1 .

Tabel 1. Hasil Produktivitas Chlorella sp. tiap Perlakuan

\begin{tabular}{cccccc}
\hline \hline & \multirow{2}{*}{$\begin{array}{c}\text { Laju Alir } \\
\text { Var }\end{array}$} & \multirow{2}{*}{$\begin{array}{c}\text { Kecepatan } \\
\text { Aliran }\end{array}$} & & \multicolumn{3}{c}{$\begin{array}{c}\text { Produktivitas Mikroalga } \\
\text { (gram/liter) }\end{array}$} \\
\cline { 5 - 6 } & (ml/detik) & $\begin{array}{c}\text { Fluida } \\
\text { (cm/detik) }\end{array}$ & 10.00 & 15.00 & $\begin{array}{c}\text { Rata- } \\
\text { Rata }\end{array}$ \\
\hline 1 & 0,54 & 17 & 0,1933 & 0,3267 & 0,2600 \\
2 & 0,36 & 33 & 0,2125 & 0,2867 & 0,2617 \\
3 & 0,11 & 23 & 0,1850 & 0,3450 & 0,2650 \\
4 & 0,36 & 14 & 0,2650 & 0,3350 & 0,3000 \\
\hline 5 & 0,61 & 23 & 0,3250 & 0,4050 & 0,3650 \\
\hline 6 & 0,18 & 30 & 0,2950 & 0,3900 & 0,3425 \\
7 & 0,54 & 30 & 0,2650 & 0,3650 & 0,3150 \\
8 & 0,36 & 23 & 0,2000 & 0,3650 & 0,2850 \\
9 & 0,18 & 17 & 0,1300 & 0,1300 & 0,1500 \\
\hline \hline
\end{tabular}

Berdasarkan Tabel 1. didapatkan kondisi optimal pada saat variasi kelima. Kondisi optimal yang diinginkan yaitu ketika penyerapan $\mathrm{CO}_{2}$ yang tinggi dengan hasil produktivitas mikroalga yang tinggi. Kondisi ini dicapai ketika injeksi $\mathrm{CO}_{2}$ yang diberikan sebesar 0,61 ml/detik dengan kecepatan aliran fluida sebesar $23 \mathrm{~cm} /$ detik.

Gas $\mathrm{CO}_{2}$ dibutuhkan untuk proses fotosintesis. Hasil penelitian menunjukkan bahwa produktivitas mikroalga pada pengambilan sampel pukul 15.00 lebih tinggi dibandingkan pada pukul 10.00. Hal ini disebabkan pada pukul 10.00 gas $\mathrm{CO}_{2}$ baru diinjeksikan selama satu jam dan belum terjadi proses fotosintesis. Sedangkan pada pukul 15.00 gas $\mathrm{CO}_{2}$ diinjeksikan selama enam jam. Hal ini menunjukkan bahwa pengaruh injeksi $\mathrm{CO}_{2}$ cukup signifikan untuk mempercepat peningkatan produktivitas mikroalga.

Perhitungan gas $\mathrm{CO}_{2}$ yang terserap tiap gram mikroalga diperoleh menggunakan persamaan gas ideal. Didapatkan, $\mathrm{CO}_{2}$ yang terserap tiap 1 gram mikroalga sebesar 0,638 gram untuk laju alir injeksi $\mathrm{CO}_{2} 0,61 \mathrm{ml} /$ detik selama enam jam. 


\section{Faktor Lingkungan}

Faktor lingkungan sangat berpengaruh terhadap pertumbuhan dan perkembangan mikroalga. Chlorella $s p$. dikultur dalam fotobioreaktor di BPPT Serpong, dengan suhu lingkungan rata-rata adalah $31^{\circ} \mathrm{C}$.

\section{Suhu}

Suhu rata-rata kultur Chlorella sp. berkisar antara $30,5^{\circ} \mathrm{C}-$ $42,7^{\circ} \mathrm{C}$. Hasil penelitian menunjukkan bahwa kultur Chlorella $s p$ mati pada hari 16 pukul 15.00 dimana pada kondisi tersebut suhu kultur mencapai $42,7^{\circ} \mathrm{C}$. Suhu kultur meningkat seiring peningkatan kecepatan aliran fluida dan peningkatan suhu lingkungan.

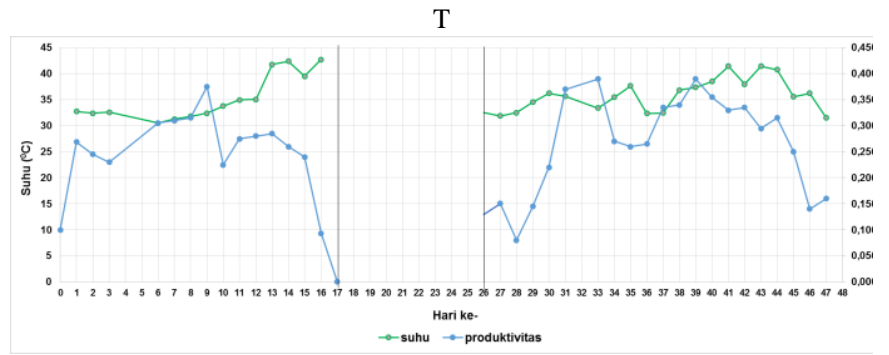

Gambar 4. Grafik Perubahan Suhu

\section{pH}

pH rata-rata kultur Chlorella sp. berkisar antara 6,38 -8,88. pH optimal bagi pertumbuhan Chlorella sp. berdasarkan hasil penelitian Wahyudi, 1999 berkisar antara 6,8-9,4. Ketika pH kultur pada 6,38 terjadi penurunan produktivitas mikroalga. Namun, penurunan produktivitas mikroalga tidak terlalu signifikan dan mikroalga masih bertahan hidup. Hal ini menunjukkan bahwa $\mathrm{pH}$ kultur masih dalam rentang $\mathrm{pH}$ yang diinginkan.

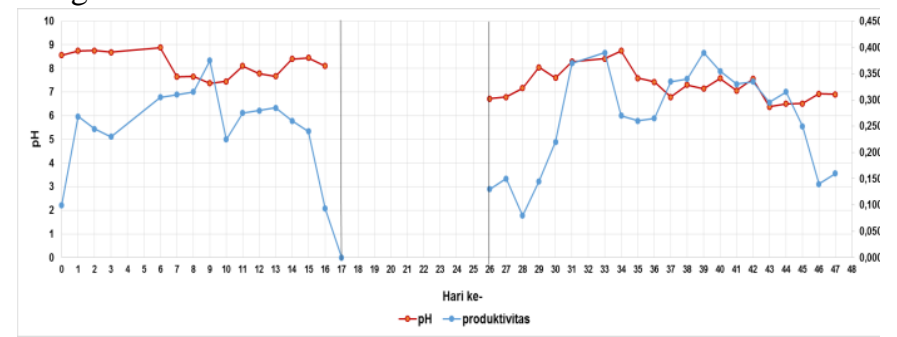

Gambar 5. Grafik Perubahan $\mathrm{pH}$

\section{Intensitas Cahaya}

Intensitas cahaya rata-rata selama penelitian berkisar antara 1.314 lux - 30.600 lux. Berdasarkan Gambar 5. hari 1 dan 40 terlihat bahwa pertumbuhan Chlorella $s p$. tetap baik walaupun pada saat kondisi cahaya yang lebih rendah maupun lebih tinggi. Hal ini menunjukkan bahwa Chlorella $s p$. masih dapat bertahan dalam perubahan kondisi cahaya yang ekstrim.

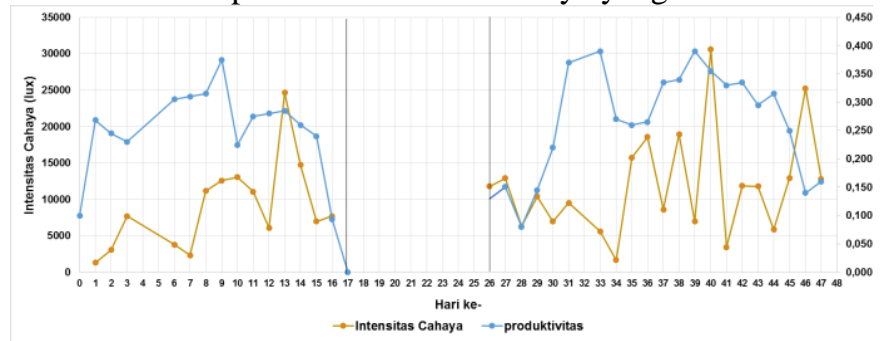

Gambar 6. Grafik Perubahan Intensitas Cahaya

\section{Optimalisasi Kinerja Fotobioreaktor berdasarkan Design- Expert}

Metode rancangan percobaan pada penelitian ini menggunakan metode respon permukaan. Model matematika yang didapatkan berdasarkan data hasil penelitian dan pengolahan dengan perangkat lunak Design-Expert dinyatakan dengan persamaan:

$\mathrm{Y}=3,25796-9,91133 \times 10^{-4} \mathrm{CO}_{2}-0,28704 \mathrm{~F}+5,25 \times 10^{-3} \mathrm{CO}_{2}{ }^{2}$ $+8,727 \times 10^{-3} \mathrm{~F}^{2}-1,51392 \times 10^{-3} \mathrm{CO}_{2} \mathrm{~F}-8,16697 \times 10^{-5} \mathrm{~F}^{3} \ldots$ (1)

Dimana:

$\mathrm{Y}=$ produktivitas mikroalga

$\mathrm{CO}_{2}=$ laju alir injeksi gas $\mathrm{CO}_{2}$

$\mathrm{F} \quad=$ kecepatan aliran fluida

Persamaan (1) dirancang dari ANOVA oleh perangkat lunak Design-Expert yang dapat digunakan untuk mencari respon prediksi berbagai hubungan kecepatan aliran fluida dan laju alir injeksi gas $\mathrm{CO}_{2}$ terhadap produktivitas mikroalga untuk kinerja fotobioreaktor. Berdasarkan prediksi yang diolah dalam perangkat lunak Design-Expert dari persamaan polynomial (1) titik optimal dari kecepatan aliran fluida dan laju alir injeksi gas $\mathrm{CO}_{2}$ disajikan pada Tabel 3 .

\begin{tabular}{cccccc}
\multicolumn{4}{c}{ Tabel 2. Titik Optimal Variasi Berdasarkan Design-Expert } \\
\hline \hline \multirow{2}{*}{ No } & \multicolumn{2}{c}{ Laju Alir Injeksi } & \multicolumn{2}{c}{$\begin{array}{c}\text { Kecepatan Aliran } \\
\text { Gas } \mathrm{CO}_{2}\end{array}$} & $\begin{array}{c}\text { Produktivitas } \\
\text { Mikroalga }\end{array}$ \\
\cline { 2 - 5 } & $\mathrm{bps}$ & $\mathrm{ml} /$ detik & $\mathrm{Hz}$ & $\mathrm{cm} /$ detik & (gram/liter) \\
\hline 1 & 10,24 & 0,61 & 38,73 & 25,82 & 0,4266 \\
\hline 2 & 10,24 & 0,61 & 39,42 & 26,28 & 0,4303 \\
3 & 10,24 & 0,61 & 25,11 & 16,74 & 0,4107 \\
4 & 10,24 & 0,61 & 35,78 & 23,85 & 0,4046 \\
5 & 10,24 & 0,61 & 27,4 & 18,27 & 0,3804 \\
6 & 10,24 & 0,61 & 28,19 & 18,79 & 0,3751 \\
7 & 10,24 & 0,61 & 28,67 & 19,11 & 0,373 \\
8 & 10,24 & 0,61 & 28,85 & 19,23 & 0,3724 \\
9 & 10,24 & 0,61 & 28,86 & 19,24 & 0,3724 \\
10 & 10,24 & 0,61 & 30,22 & 20,15 & 0,3713 \\
11 & 8,3 & 0,5 & 35 & 23 & 0,314 \\
12 & 4,1 & 0,25 & 35 & 23 & 0,2673 \\
13 & 4,13 & 0,25 & 35 & 23 & 0,267 \\
\hline 14 & 8,54 & 0,51 & 35 & 23 & 0,3222 \\
\hline 15 & 8,2 & 0,49 & 35 & 23 & 0,3108 \\
16 & 3,58 & 0,22 & 35 & 23 & 0,2744 \\
17 & 8,25 & 0,495 & 35 & 23 & 0,3124 \\
18 & 7,42 & 0,45 & 35 & 23 & 0,2888 \\
19 & 3,45 & 0,21 & 35 & 23 & 0,2766 \\
20 & 5,19 & 0,31 & 35 & 23 & 0,2616 \\
\hline \hline
\end{tabular}

Hasil analisis dari Design-Expert menunjukkan bahwa ratarata produktivitas mikroalga mencapai 0,3222 gram/liter ketika diinjeksi $\mathrm{CO}_{2}$ sebesar $0,51 \mathrm{ml} /$ detik dan mengatur kecepatan aliran fluida pada $23 \mathrm{~cm} /$ detik. Rata-rata produktivitas mikroalga yang lebih tinggi dapat dicapai dengan menambahkan injeksi $\mathrm{CO}_{2}$ sebesar $0,61 \mathrm{ml} /$ detik dan kecepatan aliran fluida pada $25,82 \mathrm{~cm} /$ detik. Produktivitas mikroalga yang dapat dihasilkan mencapai 0,4266 gram/liter.

Kecocokan yang terbaik dari model diperiksa oleh koefisien determinasi $\left(\mathrm{R}^{2}\right)$. Dalam percobaan ini, nilai $\mathrm{R}^{2}$ yang didapatkan adalah 0,9467. Hal ini menunjukkan bahwa prosentase pengaruh variabel (kecepatan aliran fluida dan laju alir injeksi gas $\mathrm{CO}_{2}$ ) terhadap produktivitas mikroalga sebesar $94,67 \%$. Sebesar $5,33 \%$ sisanya dipengaruhi oleh faktor lain yang tidak dijelaskan dalam model penelitian ini. 


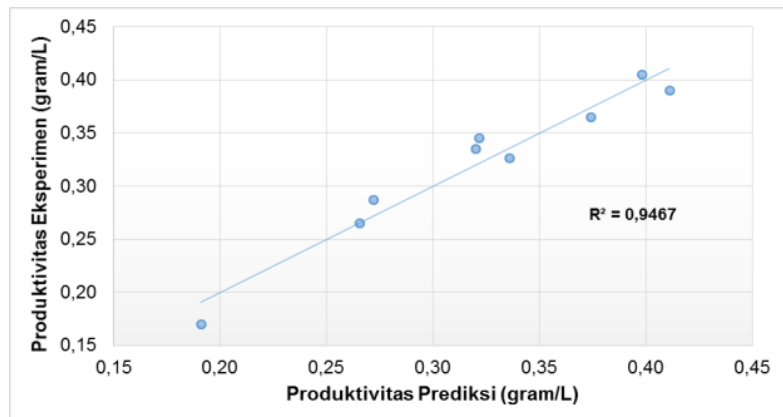

Gambar 7. Grafik Perbandingan Produktivitas Mikroalga Hasil Penelitian dengan Prediksi Hasil Simulasi

\section{E. Rekomendasi Pengoperasian Fotobioreaktor Skala Industri}

Berdasarkan hasil pengujian fotobioreaktor dari penelitian ini, dapat direkomendasikan beberapa hal sebagai berikut:

1. Apabila reaktor diletakkan di luar ruangan, dianjurkan untuk menutup bagian atas reaktor. Paparan sinar matahari langsung dapat menyebabkan mikroalga mati.

2. Apabila reaktor diletakkan di dalam ruangan, dapat ditambah dengan lampu LED sebagai cahaya yang diperlukan mikroalga selama proses fotosintesis.

3. Kultur atau benih mikroalga yang akan dimasukkan ke dalam fotobioreaktor minimum $10 \% \mathrm{v} / \mathrm{v}$ reaktor.

4. Kultur mikroalga dan media yang digunakan diusahakan sangat steril untuk menghindari kontaminasi.

5. Pemberian nutrisi dianjurkan setiap 2-5 hari sekali.

6. Apabila suhu kultur mikroalga melebihi $37^{\circ} \mathrm{C}$ dianjurkan untuk menambahkan cooling system.

7. Sirkulasi dan aerasi yang konstan dan stabil memberikan pengaruh yang signifikan terhadap pertumbuhan mikroalga.

8. Otomatisasi sistem separasi dan injeksi $\mathrm{CO}_{2}$ sangat diperlukan untuk reaktor yang berjalan secara kontinu.

9. Kecepatan aliran fluida yang tinggi akan mengakibatkan peningkatan suhu kultur. Kecepatan aliran fluida yang lebih tinggi membutuhkan daya yang lebih besar.

10. Pembersihan reaktor untuk skala yang lebih besar dianjurkan menggunakan ozonisasi atau ultraviolet karena lebih ramah lingkungan.

11. Disarankan untuk melakukan numbering up dengan mempertimbangkan sensitifitas mikroalga terhadap perubahan panjang dan diameter pipa.

\section{KESIMPULAN}

Teknologi fotobioreaktor mikroalga diketahui mampu menyerap gas $\mathrm{CO}_{2}$ dengan menghasilkan biomass mikroalga yang yang dapat dimanfaatkan kembali. Hasil optimalisasi variabel (kecepatan aliran fluida dan laju alir injeksi gas $\mathrm{CO}_{2}$ ) dapat digunakan sebagai rekomendasi pelaksanaan scaling up fotobioreaktor untuk skala yang lebih besar. Hasil optimalisasi ini nantinya dapat digunakan untuk pembuatan fotobioreaktor untuk menyerap gas $\mathrm{CO}_{2}$ dari cerobong asap industri dalam rangka mitigasi global.

\section{UCAPAN TERIMA KASIH}

Penulis mengucapkan terima kasih kepada Pusat Teknologi Lingkungan, Badan Pengkajian dan Penerapan Teknologi (BPPT), Serpong yang telah memberikan kesempatan untuk mengerjakan proyek fotobioreaktor mikroalga ini. Terima kasih pula telah menyediakan tempat, bahan, alat, dan dana yang diperlukan selama pelaksanaan penelitian.

\section{DAFTAR PUSTAKA}

[1] Barbosa, M.J.G.V. 2003. "Microalgal Photobioreactors: Scale Up and Optimisation". Thesis, Wageningen University, Wageningen, The Netherland - with summary in Dutch, ISBN: 90-5808-898-7.

[2] Center of Climate and Energy Solution (C2ES). 2012. "Carbon Capture and Storage". <URL:http://www.c2es.org/technology/factsheet/CCS> Diakses pada 09-10-2015. 09.33.

[3] Franca, R.M.C. dan Adisa, A. 2015. "Carbon Capture, Storage and Utilisation Technologies: A Critical Analysis and Comparison of Their Life Cycle Environmental Impacts". Journal of $\mathrm{CO}_{2}$ Utilization. Vol. 9 , Hal. 82-102.

[4] Hadiyanto., Istiyantyo, S., Andri, C. K., dan Silviana. 2010. "Produksi Mikroalga Bebiomasa Tinggi dalam Bioreaktor Open Pond". Prosiding Seminar Nasional Teknik Kimia. ISSN 1693 - 4393.

[5] Hanif, M., Atsuta, Y., Fujie, K., dan Daimon, H. 2012. Supercritical Fluid Extraction of Bacterial and Archaeal Lipid Biomarkers from Anaerobically Digested Sludge. Internatioal Journal of Molecular Sciences. ISSN: 1422-0067.

[6] Hanif, M. dan Dian, P.D. 2015. "Perancangan Proses Konversi Mikroalga Menjadi Biofuel sebagai Inovasi Teknologi Ramah Lingkungan". Prosiding Pertemuan Ilmiah Nas BPPT. ISBN: 978-602-1124-78-9.

[7] Kementerian Lingkungan Hidup. 2012. "Pedoman Inventarisasi Gas Rumah Kaca Nasional”. Buku I Pedoman Umum. INV/KLH/290612.

[8] Mulyanto, A. 2010. "Mikroalga (Chlorella sp.) sebagai Agensia Penambat Gas Karbon Dioksida". Jurnal Hidrosfir Indonesia. Vol. 5, No. 2, Hal. 13 - 23, ISSN 1907-1043.

[9] Pitriana, P. dan Rahmatia, D. 2008. Bioekspo, Menjelajah Alam dengan Biologi. Solo: Jatra Graphics.

[10] Santoso, A.D., Rahmania, A.D., dan Joko. P.S. 2012. "Mikroalga untuk Penyerapan Emisi $\mathrm{CO}_{2}$ dan Pengolahan Limbah Cair di Lokasi Industri”. Jurnal Teknik Lingkungan. ISSN: 1441-318X, Hal. 133-140. Jakarta, April 2012.

[11] Setiawan, A., Rahmania, A.D., Arif, D.S., Abdil, H.S., dan Kardono. 2009. "Penerapan Teknologi Fotobioreaktor Mikroalga Jenis Air-Lift untuk Menyerap Emisi Gas $\mathrm{CO}_{2}$ ". Jurnal Teknik Lingkungan. ISSN: 1441-318X, Hal. 49-56. Jakarta, Juni 2009.

[12] Sopiah, N., Adi, M., dan Sindi, S. 2012. "Pengaruh Kelimpahan Sel Mikroalgae Air Tawar (Chlorella sp.) terhadap Penambatan Karbondioksida". Jurnal Teknik Lingkungan. Vol.14, No.1, Hal. 1-6. Januari 2013.

[13] UNFCCC. 2008. "Carbon Dioxide Capture and Storage (CCS) in Geological Formations as Clean Development Mechanism (CDM) Projects Activities (SBSTA)". <URL:https://cdm.unfccc.int/about/ ccs/docs/CCS_geo.pdf>. Diakses pada 09-10-2015. 08.29.

[14] Wahyudi, P. 1999. "Chlorella: Mikroalgae Sumber Protein Sel Tunggal”. Jurnal Sains dan Teknologi Indonesia Vol. 1, No.5, Halaman 35 - 41.

[15] Wang, B., Li, Y., Wu, N., dan Lan, C.Q. 2008. " $\mathrm{CO}_{2}$ Bio-Mitigation Using Microalgae". Applied Microbiology and Biotechnology. Vol. 79, No. 5, Hal. 707 - 18, ISSN: 1432-0614.

[16] Widyaningrum, N.F., Bambang, S., dan M. Bagus, H. 2013. "Studi Eksperimental Fotobioreaktor Photovoltaic untuk Produksi Mikroalga (Nannochloropsis oculata)". Jurnal Biopress Komoditas Tropis Vol.1 No.2. Malang: Jurusan Keteknikan Pertanian - Universitas Brawijaya. 